\title{
Movimientos artísticos en la obra de Arturo Cerdá y Rico (1844-1921). Una aportación a la historia de la fotografía en España
}

\author{
Emilio luis lara López y María José Martínez Hernández \\ Grupo de investigación. Universidad de Jaén
}

\begin{abstract}
RESUMEN
En la historia de la fotografía española,

merece destacarse la obra de Arturo Cerdá y Rico (1844-1921), un amateur que

hizo miles de fotografías y que conoció perfectamente los movirnientos artísticos de la época. La obra fotográfica de Cerdá

y Rico responde a la mentalidad

característica de la burguesía, y él demuestra un perfecto conocimiento de las innovaciones artísticas fotográficas de finales del siglo xix y principios del siglo xx.
\end{abstract}

\section{Palabras clave:}

Historia de la fotografía, movimientos artísticos, burguesía.

\section{ABSTRACT}

In the history of the Spanish photography, it is necessary to highlight Arturo's work Cerdá $y$ Rico (1844-1921), an amateur that made thousands of photography's and that he met the artistic movements of the time perfectly. The photographic work of Cerdá y Rico responds to the characteristic mentality of the bourgeoisie, and he demonstrates a perfect knowledge of the photographic artistic innovations of final of the XIX century and principles of the XX century.

Key words:

History of the photography, bourgeoisie, artistic movements.

Los análisis centrados en la historia de la fotografía ${ }^{1}$ adolecen todavía en nuestro país de una problemática mal resuelta en el ámbito universitario, pues los historiadores - pertenecientes a diferentes áreas académicas- no terminan de ponerse de acuerdo en qué sitio encasillarla. Así, la historia de la fotografía es reivindicada por los historiadores contemporaneistas, del arte $\mathrm{y}-$ con algunas matizaciones- antropólogos, e incluso realizan determinadas vindicaciones coleccio-

- Hodierno, una sintesis válida de aproximación desde una óptica general es la de SovGEZ, M. ${ }^{a}$ L.: Historia de la fotografía, Madrid, Cátedra, 1981. Para el caso español FonTANELLA, L.: La historia de la fotografía en España desde sus origenes hasta 1900, Madrid, EI Viso, 1981. 
nistas, galeristas y museólogos. Quizá habría que tomar una postura análoga a la de las universidades anglosajonas, que en lugar de establecer fronteras rígidas e inamovibles en lo que atañe a la historia de la fotografía, suelen incardinarla en el terreno feraz de los cultural studies, es decir, habría que estudiarla desde el ámbito de las Humanidades ${ }^{2}$, entendidas éstas como un compendio de diversas disciplinas, pues desde una interiorización de la historia del arte, de la contemporánea y de la antropología serían mucho más fructíferas las investigaciones acerca de la historia de la fotografía en España ${ }^{3}$. Así, al historiador de la fotografía le competería «la reconstrucción de la mirada que hizo posible la aparición de una imagen fotográfica en un determinado momento " ${ }^{4}$, lo que implica que es menester conocer los precedentes de esa mirada nacida en el siglo XIX - a partir de 1839, año de invención del daguerrotipo, sobremanera las interrelaciones habidas entre la pintura y la fotografía a lo largo de la centuria decimonónica ${ }^{5}$.

No obstante, en lo concerniente al terreno de la historia del arte -que es lo que ahora viene al caso-, la producción fotográfica de Arturo Cerdá y Rico ${ }^{6}$ resulta de enorme interés en el campo de la historia de la fotografía española por variadas razones, entre las cuales sobresale el hecho de haber conformado una ingente colección de placas estereoscópicas ${ }^{7}$. Para tener una cabal visión de conjunto de la fotografía de Cerdá, creemos indispensable integrar su obra en el puzzle de la fotohistoria nacional e internacional, pues sólo así se puede llegar a valorar adecuadamente el nivel de este fotógrafo amateur, el cual siempre mantuvo un cordón umbilical con las novedades fotográficas, ya que estaba suscrito a prestigiosas revistas especializadas, participó en varios concursos fotográficos -dentro y fuera del país-, se incluyeron fotos suyas en alguna publicación ex-

2 LARA LóPEZ, E. L.: La religiosidad popular pasionista contemporánea (Jaén, 1859-1978). Una historia a través de la fotografía como fuente documental, Jaén, Instituto de Estudios Giennenses, 2004.

${ }^{3}$ Es conveniente acudir a RIEGO, B.: "La historiografía española y los debates sobre la fotografía como fuente histórica», Ayer, 24, 1996, págs. 91-111. Igualmente es interesante RIEGo, B. y VEGA, C.: Fotografía y métodos históricos: dos textos para un debate, Santander, Universidad de Cantabria, 1994.

4 VEGA, C.: «Divergencias, correspondencias: extravíos de la fotografía en la Historia del Arte», Historia de la Fotografía del siglo xix en España: una revisión metodológica, Pamplona, Gobierno de Navarra, 2002, pág. 137.

5 SCHWARZ, H.: Art and Photography. Forerunners and Influences, Chicago, The University of Chicago Press, 1987, y también ver GALASSI, P.: Before Photography. Painting and the Invention of Photography, New York, The Museum of Modern Art, 1981. Asimismo, ver RamíeZ, J. A.: Medios de masas e historia del arte, Madrid, Cátedra, 1997, págs. 85-96 y 131-142.

6 La obra de Arturo Cerdá y Rico ha sido dada a conocer por la terna de autores CeRdá PUGNAIRE, J. A., Lara Martín-Portugués, I. y Pérez Ortega, M. U.: «Imagen de la mujer giennense en la obra fotográfica del Dr. Cerdá y Rico", El Toro de Caña, 6, 2001, págs. 151-216; Del tiempo detenido. Fotografía etnográfica giennense del Dr. Cerdá y Rico, Jaén, Diputación Provincial de Jaén, 2001 y Registro de memorias. La obra fotográfica del Dr. Cerdá y Rico, Jaén, Instituto de Estudios Giennenses, 2002.

7 Para cotejar la obra estereoscópica de Cerdá y Rico con la de otros operadores aficionados, por ejemplo, ver el libro Fotografías estereoscópicas de Eustasio Villanueva (Burgos, años 20), Madrid, Ministerio de Educación-Diputación Provincial de Burgos, 2002. 
tranjera, tuvo que ser un asiduo espectador de proyecciones cinematográficas, puesto que en su obra interioriza y procesa el novedoso lenguaje fílmico y su técnica incorporándolos a determinadas fotografías, frecuenta estilos fotográficos distintos -e incluso antagónicos - tales como el pictorialismo, la fotografía directa y el reportaje gráfico, se integró en los cenáculos intelectuales granadinos, se convirtió de alguna manera en el alma mater de una tertulia de aficionados fotográficos jiennenses ${ }^{8}$, se interesó vivamente por la influencia de la pintura en la fotografía, viajó con su cámara por diferentes zonas de España y de otros países europeos y llegó hasta tierras norteafricanas.

Arturo Cerdá, nacido en Monóvar (Alicante) en 1844, por razones familiares - sus padres eran unos comerciantes alicantinos y propietarios acomodados de Monóvar- y profesionales -ejercía la medicina, cuyo título obtiene en 1868-, pertenecía a los estratos superiores de la burguesía provincial jiennense desde que en 1871 se afincó profesionalmente en el pueblo de Cabra del Santo Cristo (Jaén), lo que además de permitirle un total desahogo económico para comprar el más moderno material fotográfico, condicionó su manera de mirar por la cámara, es decir, los esquemas mentales y los valores propios de la clase media-alta decidían de antemano qué era fotografiable y qué no, pues el acto de disparar la cámara explicitaba una previa estructura ideológica ${ }^{9}$. A nuestro entender, la condición de médico de Cerdá es algo de suma trascendencia para comprender las claves de su producción fotográfica, pues los facultativos, como se verá más adelante, estarán en una posición inmejorable para desarrollar a placer esta afición.

El grueso de los aficionados pertenecía a la mesocracia, y sobre todo los del segmento alto de esta clase media podían permitirse el lujo de adquirir el último grito de aparatos y componentes fotográficos, lo cual redundaba en una mejora constante de la calidad de sus fotografías. Los médicos, desde la restauración canovista -1874-, estuvieron en estrecho contacto con la fotografía, pues la publicación de fotos en revistas médicas les era de gran utilidad. Esto explica que no pocos amateurs fueran facultativos, porque habían llegado a la práctica fotográfica a través del estudio y puesta al día de su profesión. Precisamente la condición de amateur le reportaría a Cerdá una absoluta libertad de acción, pues no estaba aherrojado por la rutina, colocado bajo la dictadura de los retratos estandarizados ni sometido a las exigencias de la clientela. El hecho de que él fotografiara para de-

8 Ver lara Martín-Portugués, I. y Lara LóPez, E. L.: La memoria en sepia. Historia de la fotografía jiennense desde los orígenes hasta 1920, Jaén, Instituto de Estudios Giennenses, 2001. Los operadores aficionados que componían el núcleo duro de la tertulia fotográfica -reunida normalmente en la capital, en concreto en el Café España, situado en la Carrera - eran Bonifacio de la Rosa Martínez, Enrique Cañada Pérez, Eduardo Arroyo Sevilla, Ramón Espantaleón Molina, Jaime Roselló Cañada y José Mediano Sáenz.

9 A este respecto ver LaRa López, E. L. y PALAGios Ramírez, J.: «La mirada de la burguesía: Jaén a través de la fotografía de principios del siglo xx», El Toro de Caña, 9, 2002, págs. 11-70. 
leite suyo y por extensión para el de su círculo más íntimo, le permitió experimentar y bucear en las nuevas tendencias fotográficas, de las que estaba tan bien informado. Eso sí, no pretendió que su obra quedase sin conocer, como demuestran los elogios recibidos por afamados operadores aficionados ${ }^{10}$, la exitosa participación en concursos ${ }^{11}$, la inserción de fotos suyas en diferentes publicaciones ${ }^{12}$ y la correspondencia cruzada con otros fotógrafos españoles, en la que éstos adjuntaban fotografías de su cosecha para que sus colegas las admirasen y conociesen su obra ${ }^{13}$. Todo esto suponía un limo vivificador para la producción de Cerdá, puesto que nunca se quedó encasillado ni se movió en el extrarradio de las más pujantes corrientes fotográficas. Así, por ejemplo, su faceta retratística, que consume una porción importante de sus instantáneas, denota el profundo conocimiento de la fotografía y pintura del siglo XIX, pues el arte de Daguerre, como es bien sabido, bebió hasta saciarse en las fuentes pictóricas, no sólo en su nacimiento sino en todo el resto de la centuria decimonónica. Aquí, por tanto, hay que hablar de sus autorretratos, pues en la bisagra del siglo XIX con el siglo Xx, numerosos aficionados trasladan a la fotografía su propia imagen y se rodean de objetos característicos de su profesión, siendo esta iconografía heredada de la pintura y harto empleada en los retratos decimonónicos de estudio. El médico investigador Santiago Ramón y Cajal, en 1900, se autorretrata con su cámara y coloca delante tres microscopios, el instrumental que mejor simbolizaba su dedicación médica. Cerdá y Rico se autorretrata en numerosas ocasiones a lo largo de su vida, bien en solitario - adopta una pose distinguida propia de su condición burguesa-, durante el proceso de revelado de negativos en el cuarto oscuro (Fig. 1), en compañía de amigos de su tertulia granadina -menudean las fotos en las que aparece el pintor López Mezquita-, con sus amigos jiennenses amateurs mientras visionan fotografías estereoscópicas, junto a sus hijos, o rodeado de sus nietos.

10 Káulak, sobrenombre de Antonio Cánovas del Castillo - sobrino del político conservador-, ensalzaria en un artículo publicado en 1904 en el número 33 de La Fotografía un conjunto de placas estereoscópicas remitidas por Cerdá a un concurso nacional — por las cuales fue galardonado con una medalla de plata. Káulak era, hacia 1900, un aficionado destacado en Madrid -ciudad en la que convivían alrededor de un millar de amateurs - que gozaba de alta consideración como fotógrafo, al ser uno de los impulsores de la Sociedad Fotográfica de Madrid.

11 Verbigracia, consigue los primeros premios en certámenes celebrados en Madrid —en 1903 y 1908 - y en Valencia -en 1906-, cosechando también un galardón en Londres en 1909.

12 Entre otras La Fotografía, La Fotografía Práctica, Photos, Graphos llustrado y la inglesa Photograms of the years.

${ }_{13}$ ¿Pudo ser esta comunicación epistolar una forma mediante la cual el luego celebérrimo fotógrafo Alfonso conociera algo de la producción de Cerdá? Como apoyo a esta hipótesis, me permito señalar que en SÁNCHEZ VIGIL, J. M.: Alfonso. Imágenes de un siglo, Madrid, Espasa, 2001, pág. 84, aparece una foto tomada en 1914 desde el interior de la puerta grande de la desaparecida madrileña plaza de toros de la carretera de Aragón: el arco neomudéjar actúa como marco del exterior, donde el torero Joselito es llevado en volandas entre una multitud. Pues bien, algunos años antes - entre cinco y diez-, Arturo Cerdá tomó una fotografía de idéntico encuadre, sólo que no registró la salida a hombros de ningún matador, sino a la gente que entraba en el coso para disfrutar de una tarde de toros. 


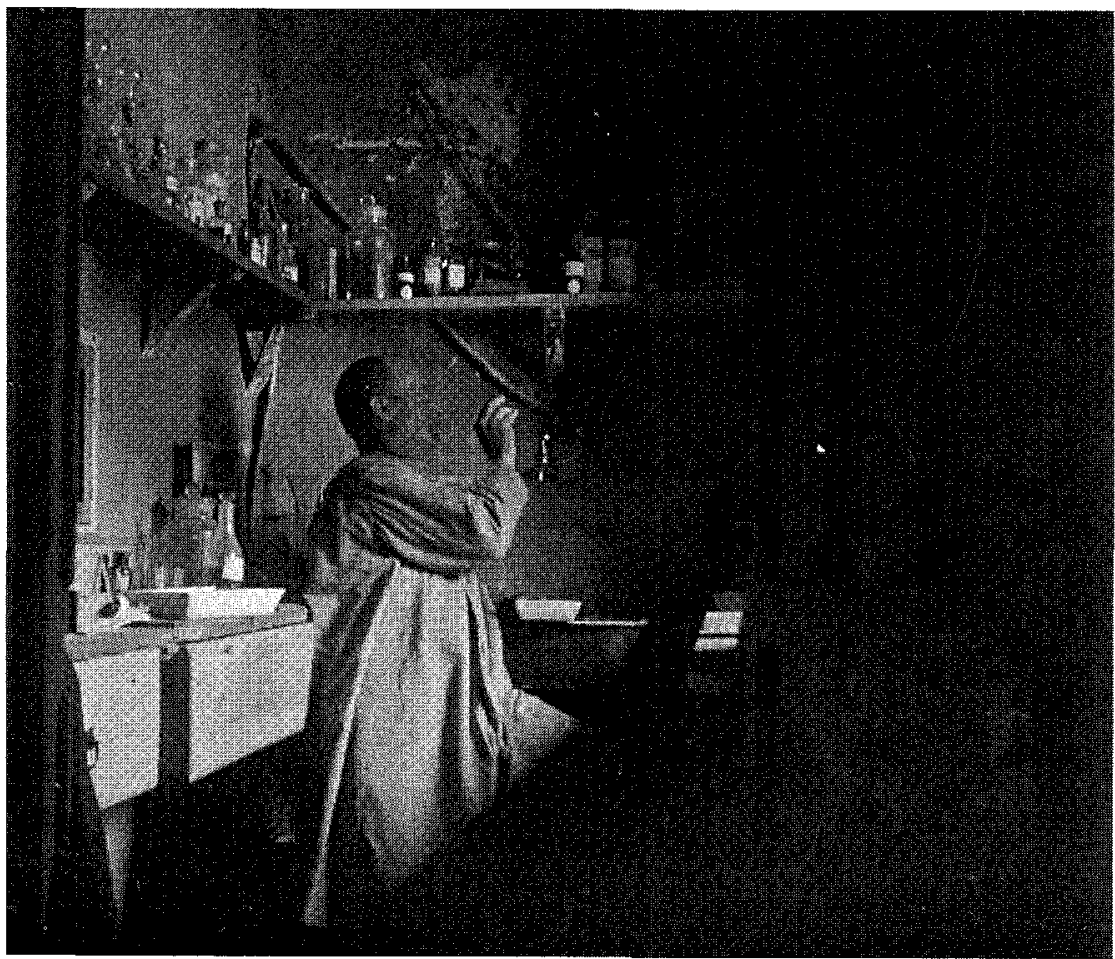

Fig. 1. Autorretrato en el cuarto oscuro. 1904.

El pictorialismo, al que se entregaría con pasión Cerdá y Rico, es uno de los movimientos fotográficos que más relación tiene con la pintura -impresionista y postimpresionista fundamentalmente-, y el corpus fotográfico pictorialista de Cerdá es en verdad admirable. Esta corriente fotográfica nace en el último tercio del siglo XIX y se practica hasta principios de la década de 1920. Su declaración de principios se articulaba en el alejamiento de la fotografía de estudio -encorsetada y amojamada según los pictorialistas-, que había devenido en una masiva mercantilización con la consiguiente degradación del arte fotográfico. El pictorialismo es por tanto una reacción contra la falta de alma de la retratística de gabinete, y cree hallar la piedra filosofal en la rompedora obra de los pintores impresionistas y postimpresionistas, con lo que el operador retoca los negativos y organiza todos los aspectos del posado del modelo - como un director de escena- para que la composición huya de la espontaneidad. Los pictorialistas - fueron legión en Europa - anhelaban que el resultado final se alejase de una copia fidedigna de la realidad, pues pensaban que la artisticidad residía en la habilidad técnica y estética 
de quien manejaba la cámara y en sus ulteriores retoques de las placas. Este movimiento fotográfico haría furor entre lo más granado de los operadores aficionados hispanos - los profesionales rechazarían en bloque este ismo fotográfico- en el primer tercio del siglo xx, por lo que Cerdá estuvo como pez en el agua en él. Káulak, Carlos Iñigo y J. Vilatobá ${ }^{14}$ practicaron la fotografía pictorialista desde variadas perspectivas, siendo los dos primeros probablemente las más directas referencias para Arturo Cerdá, ya que, al igual que éstos, prefería los planteamientos puristas o simbolistas. Los pictorialistas puristas -o academicistas- imitaban al máximo las escenas pictóricas (Fig. 2), y los simbolistas recreaban escenarios y decorados

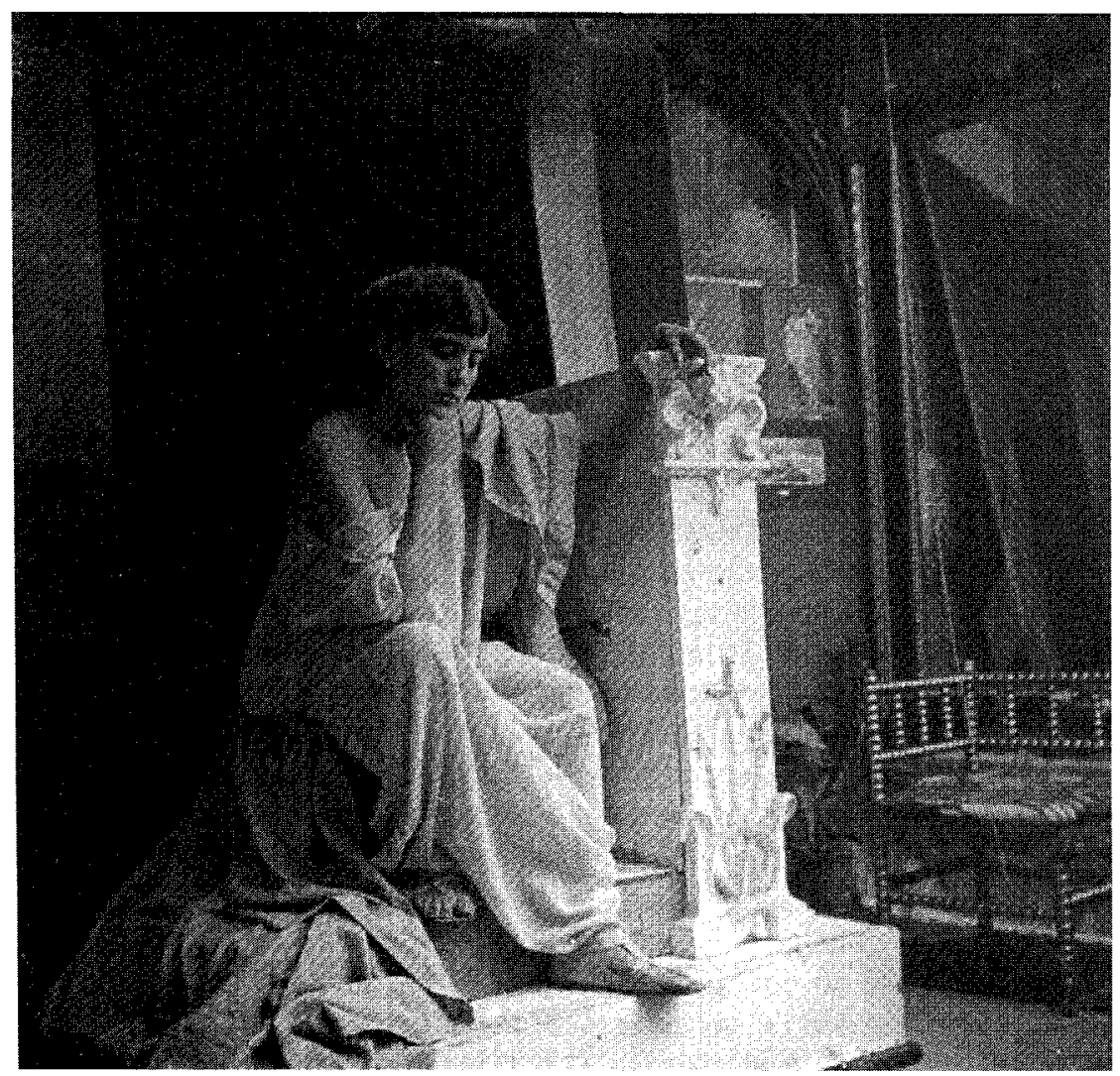

Fig. 2. Modelo en el estudio del pintor López Mezquita. 1905.

${ }^{14}$ Otros destacados pictorialistas coetáneos de Cerdá fueron Diego Calvache, Pedro Casas Abarca, Vicente Gómez Novella y Luis de Ocharan. 


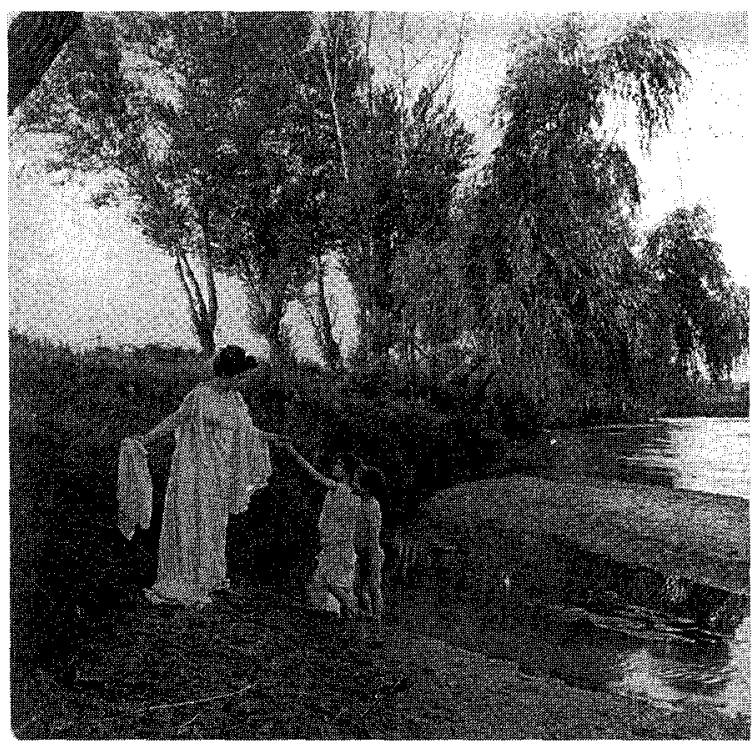

Fig. 3. Escena simbólica. 1906.

en sus escenas de fuerte contenido alegórico ${ }^{15}$ (Fig. 3), y en ambas modalidades pictorialistas descollará Cerdá y Rico.

Pero precisamente, una de las variantes del pictorialismo más genuinas en la obra de este fotógrafo será la serie de retratos realizados a sus nietos - con especial predilección por dos de ellos-, pues acostumbraba a tomarlos como obedientes modelos para generar un amplísimo repertorio de gestos y disfraces gracias, todo hay que decirlo, a las buenas dotes naturales mostradas por los niños. Este interesante conjunto fotográfico - sin parangón con el de otro operador amateur o profesional a escala nacional-, creemos que recibe una clara influencia del cinematógrafo ${ }^{16}$, porque la particular mirada del cine es interiorizada por Arturo

15 Una fotografía del simbolismo pictorialista - se trata de una placa autocroma de 1907-, reproducida en Registro de memorias..., op. cit., pág. 179, representa a una joven con túnica blanca y manto carmesí - a la manera romana - al borde de un estanque rodeado de vegetación, y esta instantánea ha recibido el influjo directo de la pintura simbolista del último ventenio del siglo xIX. El simbolismo pictorialista en la fotografía se extenderá al menos hasta la década de 1920, pues sin salir de España, el marqués de Santa María del Villar, en 1922, realizaría unas fotografías de este tipo - con una derivación mitológica- tituladas La farsa de la Walkiria que pueden verse en Historia de la Fotografía del siglo XIX..., op. cit., pág. 116 .

16 No hay que perder de vista que el cine es consecuencia directa de la fotografía, con lo cual los operadores aficionados y profesionales recibieron el cinematógrafo como un fabuloso medio expresivo, y por otro lado, fueron muchos los terrenos comunes visitados por la fotografía y los espectáculos precinematográficos, como ponen de manifiesto los magníficos trabajos de FrUTOS EsTEBAN, F. J.: La 
Cerdá, que traslada a sus placas los enfoques, encuadres y temáticas del cinema muy inteligentemente, de manera que realizó numerosas tiradas fotográficas secuenciales a modo de fotogramas. Un ejemplo de esto es la serie de fotografías que representan escenas de borrachos en la taberna o en la calle (Fig. 4), o también las que se desarrollan en el interior de estudios de escultores y que tienen un fondo irónico (Fig. 5), e incluso los retratos de sus dos nietos modelos por excelencia están inspiradas muchas veces en el cine cómico americano (Fig. 6) o en las películas de aventuras ${ }^{17}$. En cualquier caso, el concepto de foto fija extraída de un

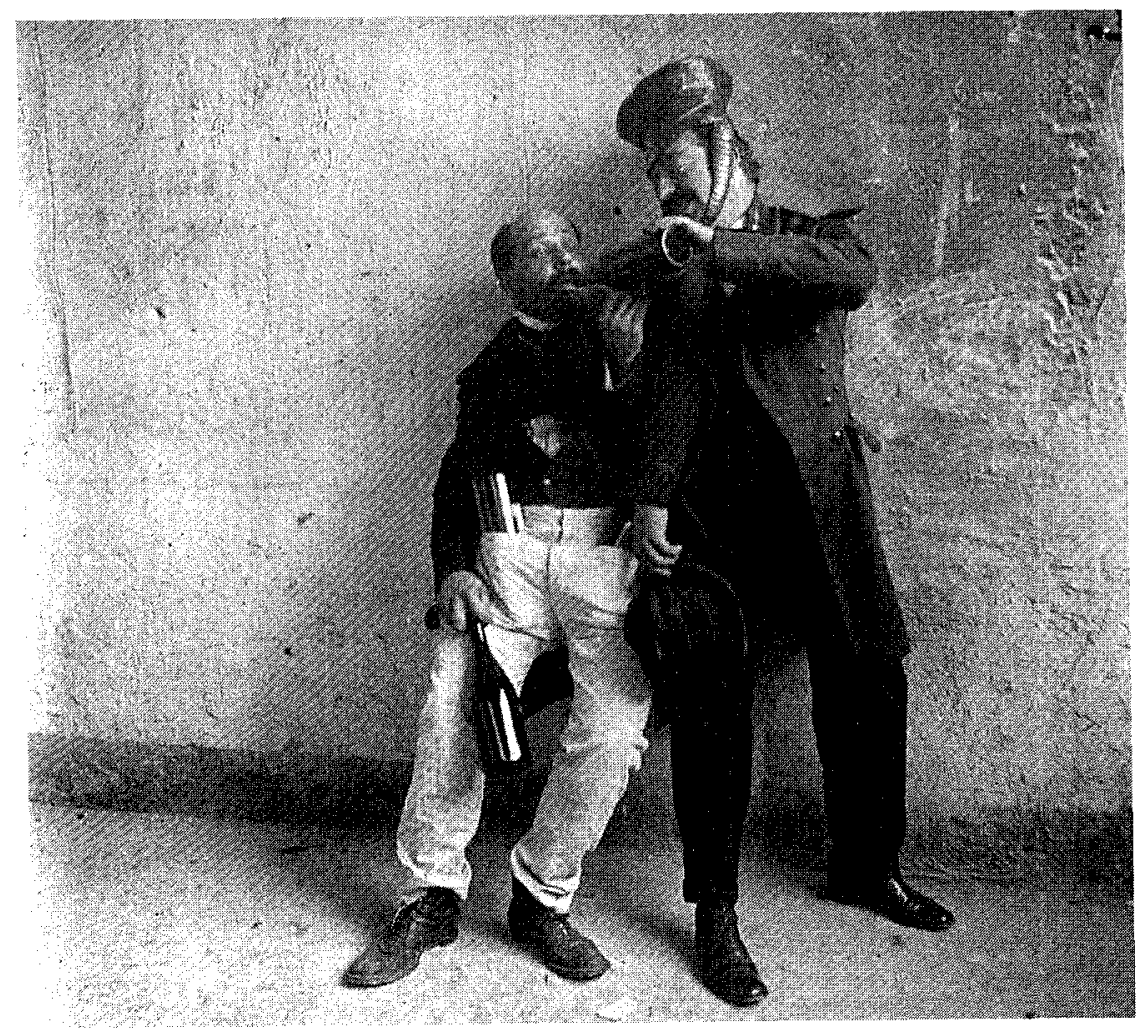

Fig. 4. Escena cómica de borrachos. 1907.

fascinación de la mirada. Los aparatos precinematográficos y sus posibilidades expresivas, Valladolid, Junta de Castilla y León, 1996, Artilugios para fascinar. Colección Basilio Martín Patino, Salamanca, Junta de Castilla y León-Ayuntamiento de Salamanca, 1999 y «Escenarios lúcidos de la memoria», en $\mathrm{Me-}$ morias de la mirada. Las imágenes como fenómeno cultural en la España contemporánea, Santander, Fundación Marcelino Botín, 2001.

17 Ver las dos obras Del tiempo detenido..., op. cit. y Registro de memorias..., op. cit. 
Movimientos artísticos en la obra de Arturo Cerdá y Rico (1844-1921)...

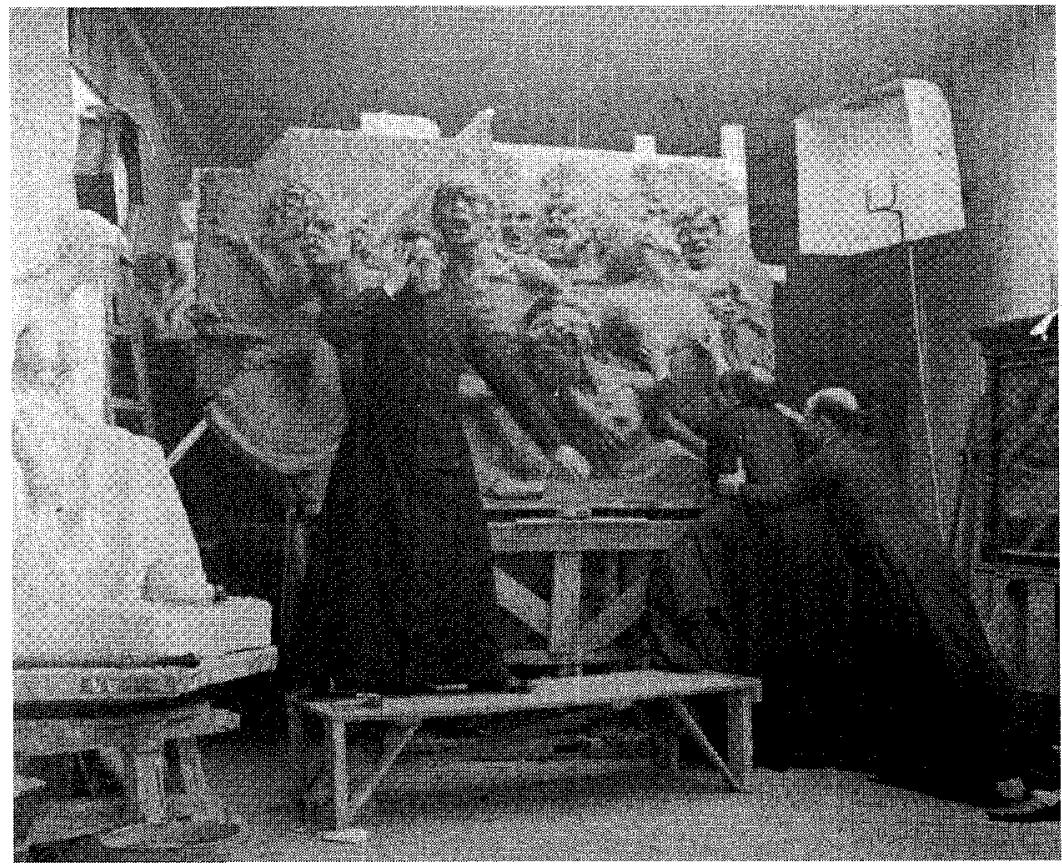

Fig. 5. Escena satírica. 1907.

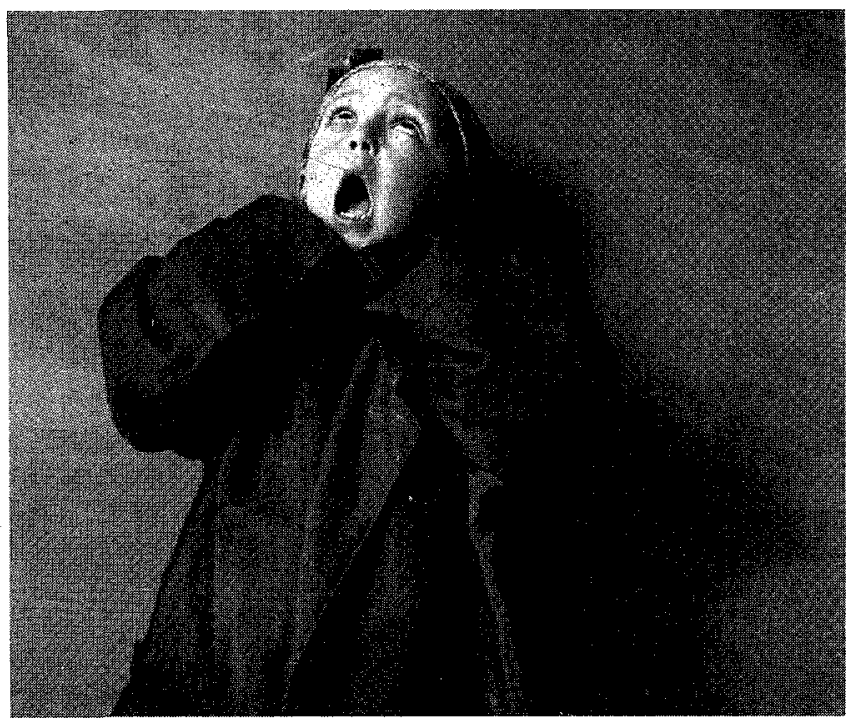

Fig. 6. Retrato de nieto. 1909. 


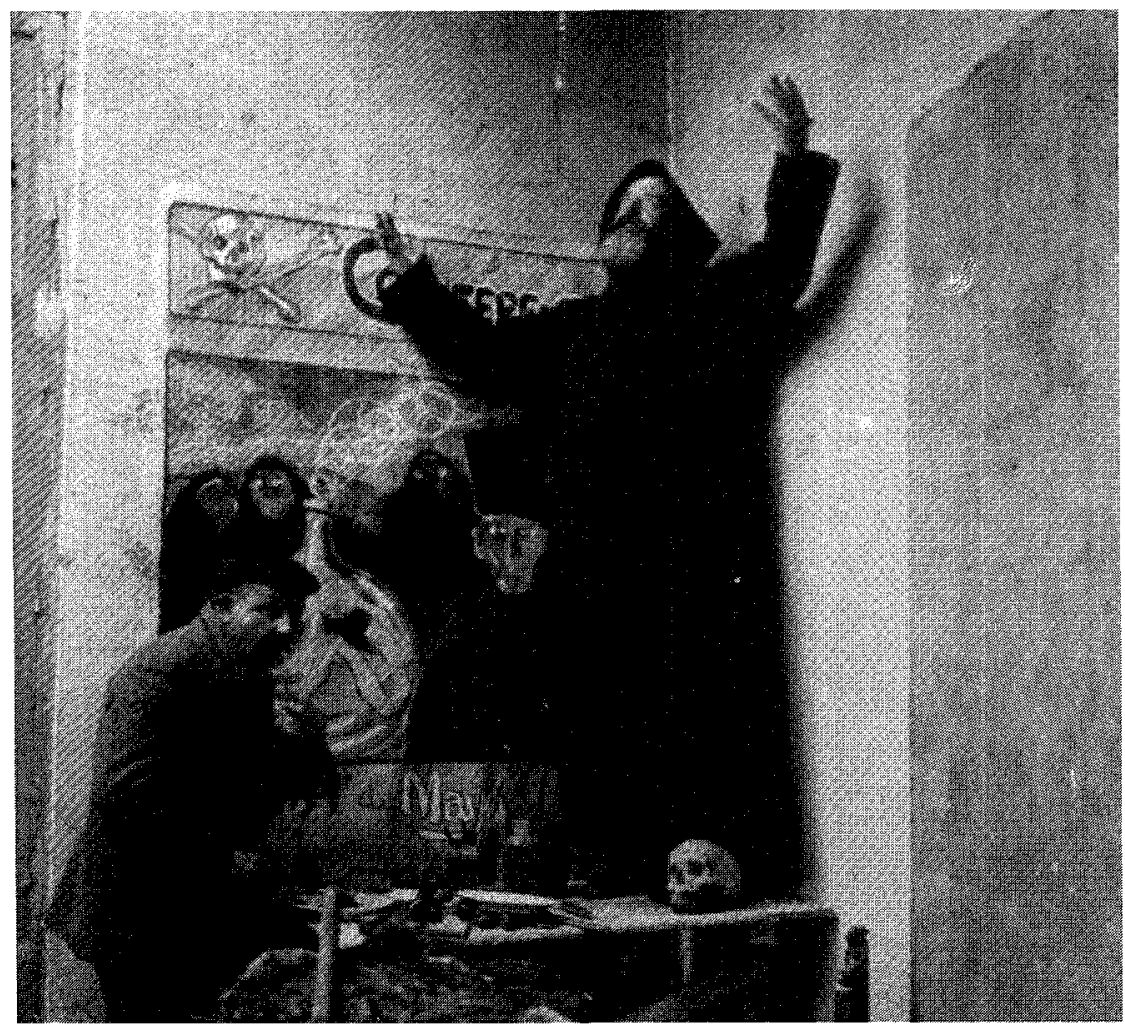

Fig. 7. Escena satírica. 1909.

film ${ }^{18}$ (Fig. 7), repercutirá tanto en Cerdá y Rico, que su obra recorrerá un camino plástico cinematografiado en sus últimos quince o dieciséis años ${ }^{19}$.

Una temática fotográfica que circuló a menudo por canales soterrados fue la erótica, que a menudo andaba por el filo de la navaja de lo artístico para enmascarar la finalidad psicalíptica. El desnudo, que contaba con una arraigada tradición

18 Ver Pérez Bowie, J. A.: Materiales para un sueño. En torno a la recepción del cine en España, 1896-1936, Salamanca, Librería Cervantes, 1996.

19 Aparte de los contactos con los cafés, locales y salas donde se proyectaran espectáculos cinematográficos que pudiera tener Cerdá gracias a sus viajes por la geografía nacional — sobre todo a Granada - en Jaén capital — cuya primera proyección de cine se remonta a 1898- a la altura de 1907 ya existía un local estable como era el Salón Norte, en el entonces Paseo de Alfonso XIII -hoy Paseo de la Estación-, que daba todas las tardes tres sesiones, a las 7, 8 y 9 de la tarde. A este respecto, es interesante el texto de ORTEGA CAMPOS, I.: «Los albores del cinematógrafo en Jaén (1808-1910)", en Jaén entre dos siglos (1875-1931), Granada, Museo Provincial de Jaén-Junta de Andalucía-La General, 2000 , págs. 171-174. 
en la pintura, fue un tema controvertido en fotografía debido al gran realismo que ésta ofrecía, pues parecía harto complicado sublimar un cuerpo desnudo sin que mediaran los pinceles, y esto se aprecia en que «los primeros desnudos fotográficos fueron posados por prostitutas" ${ }^{20}$. La estrecha amistad de Arturo Cerdá con pintores como López Mezquita, Rodríguez Acosta e incluso Sorolla influyó mucho en esta modalidad fotográfica, pues habitualmente las modelos posaban adoptando poses pretendidamente pictóricas (Fig. 8) bien en el estudio de un pintor, en escenarios campestres ${ }^{21}$ o incluso en las calles de Tánger (Fig. 9). A veces es difícil trazar con nitidez la frontera entre las fotografías de desnudos femeninos de raíz pictorialista de aquéllas que estaban pensadas para abastecer el mercado de fotos eróticas, aunque las instantáneas de Cerdá y Rico tienen siempre un regusto artístico ligado a la iconografía pictórica de finales del siglo XIX y primeros años del siglo $x x$ que las alejan de las burdas fotografías hechas por manos anónimas destinadas al mercadeo ${ }^{22}$. Operadores que realizaron incursiones en este tipo de fotografía de desnudos fueron Ceferino Yanguas, Emili Vilá, Masana, Luis Escobar y Emilio Meléndez de la Puente.

La fotografía en color también fue practicada por Cerdá con éxito nada más nacer este procedimiento a principios del siglo xx, pues entre 1908 y 1912 tomará bastantes placas autocromas de retratos y bodegones. Las placas autocromas fueron un invento de los hermanos Lumière que despertó muchas esperanzas entre los fotógrafos. La contemplación de estas instantáneas a través de una lupa como consecuencia de la técnica empleada - daba la sensación de estar viendo un cuadro puntillista de Seurat, por eso las reproducciones de estas placas ofrecen un aspecto granulado. El proceso para obtener placas autocromas resultaba complicado y caro, por lo que sólo estaba al alcance de un reducido grupo de fotógrafos cuyo nivel adquisitivo podía permitirle obtener fotos en color. Las naturalezas muertas a base de jarrones con flores variadas serán las predilectas de Cerdá, aunque también incorpora a los bodegones piezas de cerámica o de cristal muy en la línea de la pintura barroca - denominada en el siglo xvII pintura del silencio-, pero no sólo se limita a repetir manidas composiciones, sino que inserta en los bodegones

20 Gubern, R.: Medios icónicos de masas, Madrid, Historia 16, 1997, pág. 32.

21 Dos fotos de desnudos en el campo tomadas en 1910 pueden contemplarse en Registro de memorias...op. cit, págs. 140-141, y estimamos que hay que conectar esto con la explosión de desnudos en plena naturaleza - como una proclama de libertad y de autenticidad-que vivieron las vanguardias históricas entre 1905 y 1914 -las cuales miraron al impresionismo y postimpresionismo-, pues pintores como Henri Matisse o Franz Marc -entre otros - revisitaron el tema de la mujer desnuda en comunión con la naturaleza.

${ }^{22}$ López MondéJAR, P.: Historia de la fotografía en España, Barcelona, Lunwerg, 1997, págs. 136137, comenta que «más ingenuos y sencillos son los anónimos desnudos de carácter popular, realizados entre la patética legión de especialistas en amores de alquiler, que posaban con la picardía abrupta, propia de los ambientes en que se improvisaban aquellas sesiones mercenarias». 


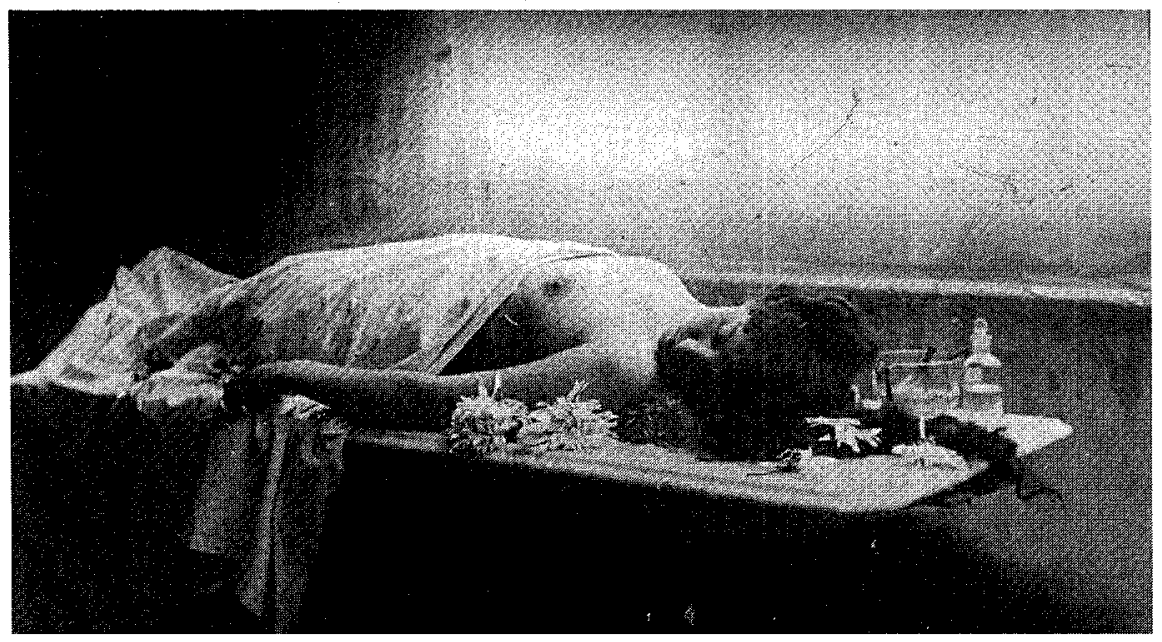

Fig. 8. Desnudo. 1905.

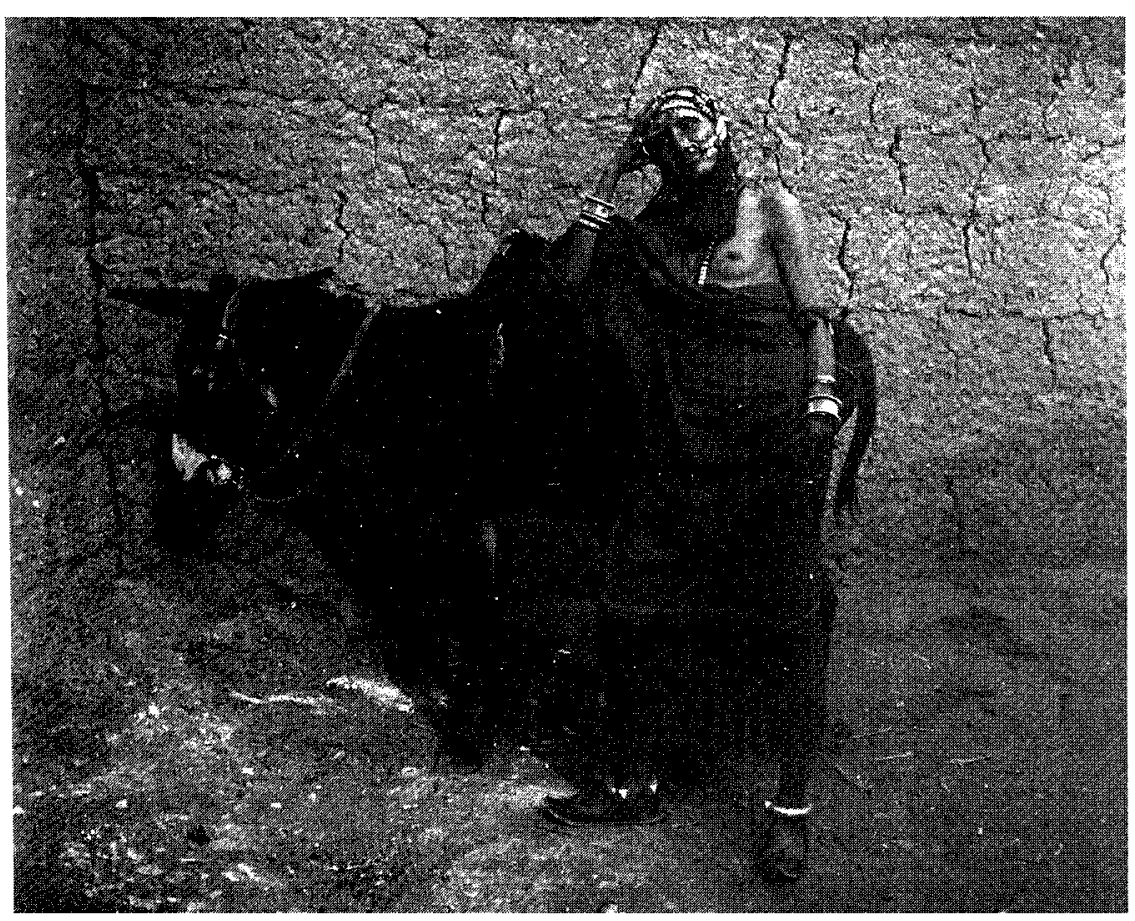

Fig. 9. Mujer en Tánger. 1907. 
elementos ornamentales y botellas que reactualizan el lenguaje de los bodegones. En este sentido, la figura referencial para Cerdá y Rico fue Santiago Ramón y Cajal, pues amén de perfeccionar el proceso de fotografiar en color ${ }^{23}$, hizo placas autocromas de bodegones de marcado acento moderno al colocar botellas de anís del Mono y de ron Negrita junto a una fuente con frutas ${ }^{24}$, y además, Cajal y Cerdá fueron amigos, como demuestra que en el patio de su casa cabrileña, Arturo Cerdá tuviese colgado un autorretrato fotográfico del célebre histólogo. Pero Cerdá y Rico no se encasilló en los bodegones autocromos, sino que es autor de numerosos retratos en color, algunos de los cuales pertenecen al pictorialismo (Fig. 10).

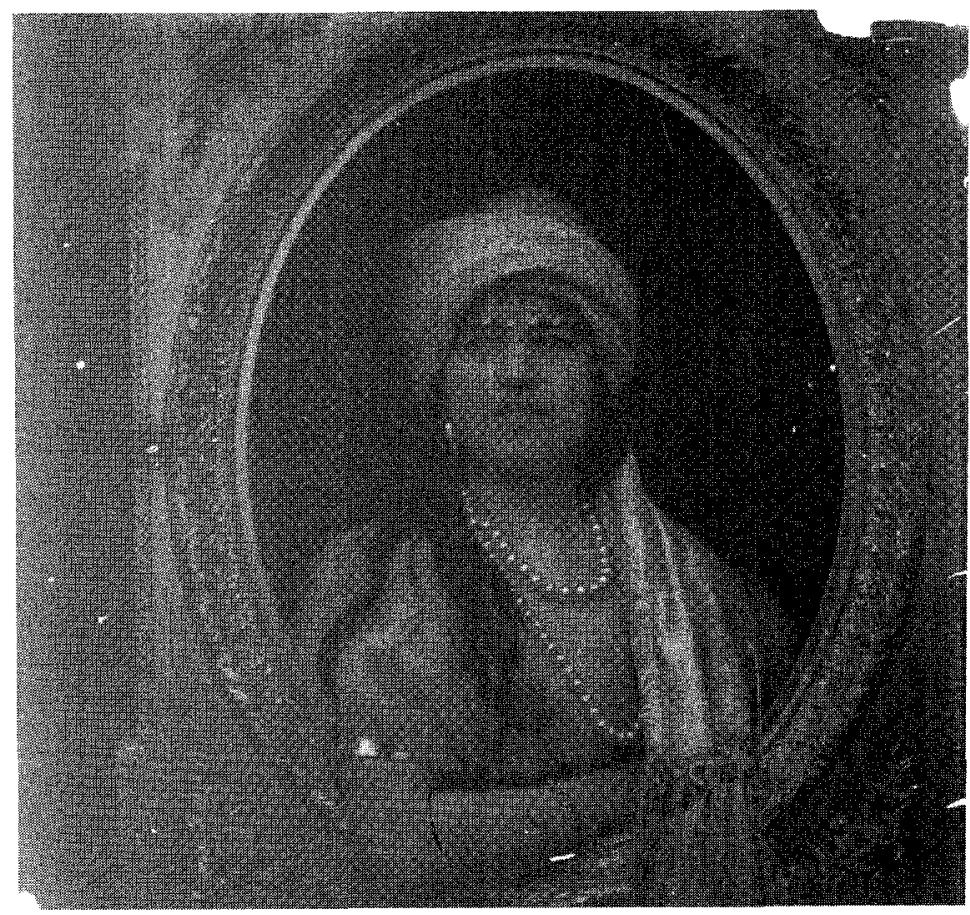

Fig. 10. Retrato orientalista. 1910.

${ }^{23}$ En 1907, Cajal publica en la revista La Fotografía el artículo «Las placas autocromas Lumière y el problema de las copias múltiples", y en 1912, sale a la luz su libro La fotografía de los colores. Bases científicas y reglas prácticas.

${ }_{24}$ Esta sugerente instantánea en color realizada en 1912 puede verse en SÁNCHEZ VIGIL, J. M. (coord.): La fotografía en España. De los orígenes al siglo xxl, Summa Artis, volumen XLVII, Madrid, Espasa Calpe, 2001, pág. 217. En paralelo, los pintores cubistas, entre 1911 y 1915 fundamentalmente, en sus naturalezas muertas -adscritas al cubismo analítico o sintético-, gustan incorporar objetos modernos como periódicos o botellas, lo que demuestra los vasos comunicantes entre fotografía y pintura, un tema en el que es obligado acudir a ScHARF, A.: Arte y fotografía, Madrid, Alianza Editorial, 1994 [1968]. 


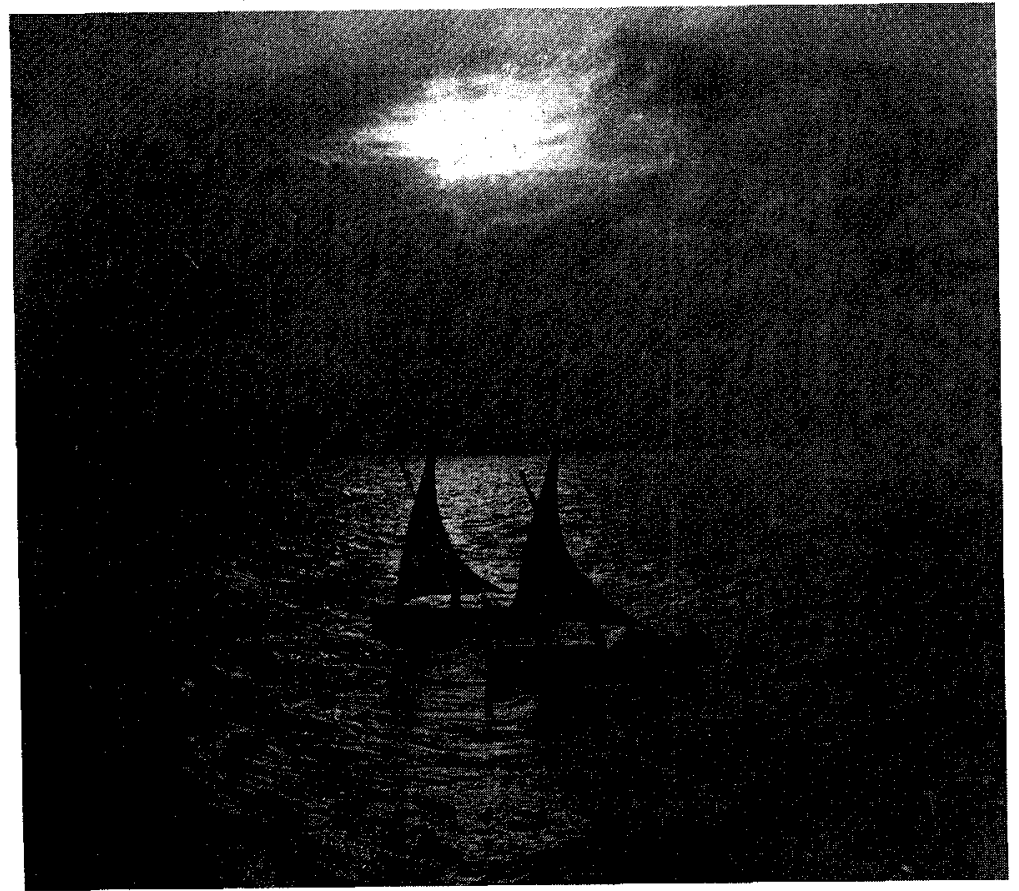

Fig. 11. Valencia. 1904.

Operadores que utilizaron placas autocromas fueron, por ejemplo, Joaquín Fungairiño y Ángel Redondo, si bien algo después que Cerdá. Asimismo hay que traer a colación otras placas, que registran parajes naturales jiennenses, y que son fotografías pioneras a nivel nacional, pues se hicieron en una fecha tan temprana como la de 1910, lo que demuestra la visión de futuro de Arturo Cerdá ${ }^{25}$. El hecho de fotografiar en color suponía estar a la última en cuanto a la técnica y lenguaje fotográficos ${ }^{26}$, y esto viene a respaldar la altura fotográfica de Cerdá y Rico. Como apéndice de la fotografía de parajes naturales, Cerdá registró obsesivamente escenas acuáticas ${ }^{27}$ (Fig. 11), en las cuales el protagonis-

25 Lo que hace a Cerdá y Rico como un avant la lettre es la calidad técnica y el empleo del color en sus fotografías de parajes naturales.

${ }_{26}$ SÁNCHEZ VIGIL, J. M.: La fotografía en España..., op. cit., pág. 211, considera que «la fotografía en color fue utilizada por los aficionados de vanguardia, mientras que los profesionales de prensa y gabinete continuaron apegados al blanco y negro".

${ }_{27}$ Otro fotógrafo que captó cursos fluviales con su cámara fue Arturo González Nieto, quien en 1904 toma una instantánea de las orillas del Sil que puede verse en RAmón TEIJELO, M. ${ }^{a}$ R.: Arturo González Nieto. Pionero berciano de la fotografía, Salamanca, Junta de Castilla y León, 2002, pág. 51. 
ta es el mar, un río, un arroyo... lo que habría que conectarlo quizá con la pintura realizada por su amigo Sorolla, que tantos matices lumínicos logró en sus lienzos en los que el mar es un elemento imprescindible, aunque también otros operadores habían tomado con anterioridad instantáneas análogas, pues de hecho, Arturo Vianna de Lima realizó en 1890 una serie de fotos - calotipos- bajo el título genérico de Nach der Natur (Hacia la naturaleza) tomadas en una isla del Mar del Norte ${ }^{28}$.

Los operadores aficionados, al no estar constreñidos a la fotografía comercial ni a la retratística de estudio, eran unos privilegiados por poder tocar varios palos y experimentar las propuestas hechas por otros amateurs. Por ello, sin duda alguna, el fenómeno del excursionismo y del turismo ${ }^{29}$, modalidades practicadas por la burguesía desde el último tercio del siglo XIX, constituían un campo inmejorable para el registro fotográfico, sobre todo desde principios del siglo $\mathrm{XX}$, pues la creación de asociaciones excursionistas y artísticas al socaire de determinadas corrientes pedagógicas dio cobertura institucional a esta práctica ${ }^{30}$. Arturo Cerdá, cámara en ristre, viajó por varias provincias andaluzas -especialmente por Jaén, Granada, Córdoba y Sevilla-, Alicante, Valencia, Toledo, Madrid (Fig. 12), Salamanca, Ávila, Barcelona ${ }^{31}$, etc. E incluso registró fotográficamente ciudades de in-

${ }^{28}$ Una de ellas, Niño pescador, aparece en NEWHALL, B.: Historia de la fotografía, Barcelona, Gustavo Gili, 2001, pág. 145.

${ }^{29}$ Las giras turísticas serán una de las costumbres más extendidas entre las clases acomodadas europeas desde los útítimos treinta años del centón decimonónico, popularizándose entre los estratos burgueses en los dos primeros decenios del siglo XX. La tarjeta postal ilustrada será un vehículo gráfico inmejorable para la comunicación interpersonal, pues además de escribir unas líneas amables, se enviaba una imagen del lugar en el que se hacía turismo y se pasaban las vacaciones. Una obra de referencia fundamental en este sentido es VV. AA. Santander en la tarjeta postal ilustrada (1897-1941), Santander, Fundación Marcelino Botín, 1997. No obstante, uno de los fermentos del crecimiento espectacular de la fotografía como vehículo de comunicación de masas tuvo sus orígenes a finales de la década de 1850, pues las fotografías de lugares exóticos y de ciudades de larga tradición cosmopolita, supusieron una especie de viaje virtual para los contempledores de estas fotos, que o bien las contemplaban en álbumes o las visionaban en los espectáculos visuales que, instalados en carpas y barracones, viajaban de feria en feria por toda España. Así, según opina RuBIo ARAGonÉs, J. C.: «Retrato y paisaje en la fotografía del siglo XIX: colecciones privadas de Madrid», en Retrato y paisaje en la fotografia del siglo XIX: colecciones privadas de Madrid, Madrid, Fundación Telefónica, 2002, pág. 31:

«Con la consolidación del viaje y su evolución hacia el turismo de masas, el auge de la fotografía excita la imaginación de los viajeros y tiene un efecto multiplicador sobre la retina turística de sensibilidad romántica. Las grandezas de la naturaleza alpina, de la arquitectura monumental y de la escultura y pintura de las ciudades italianas, tanto como las imágenes de muerte y destrucción de Pompeya, componen una irresistible oferta fotográfica para el viajero».

30 Un exponente era Diego Quiroga y Losada, como puede verse en el artículo de LATORRE, J.: «Santa María del Villar: fotógrafo turista», en Historia de la Fotografía del siglo xix en España: una revisión..., op. cit., págs. 103-123.

${ }_{31}$ Un surtido muestrario de estas fotografías puede verse en Registro de memorias..., op. cit., págs. 247-394. 


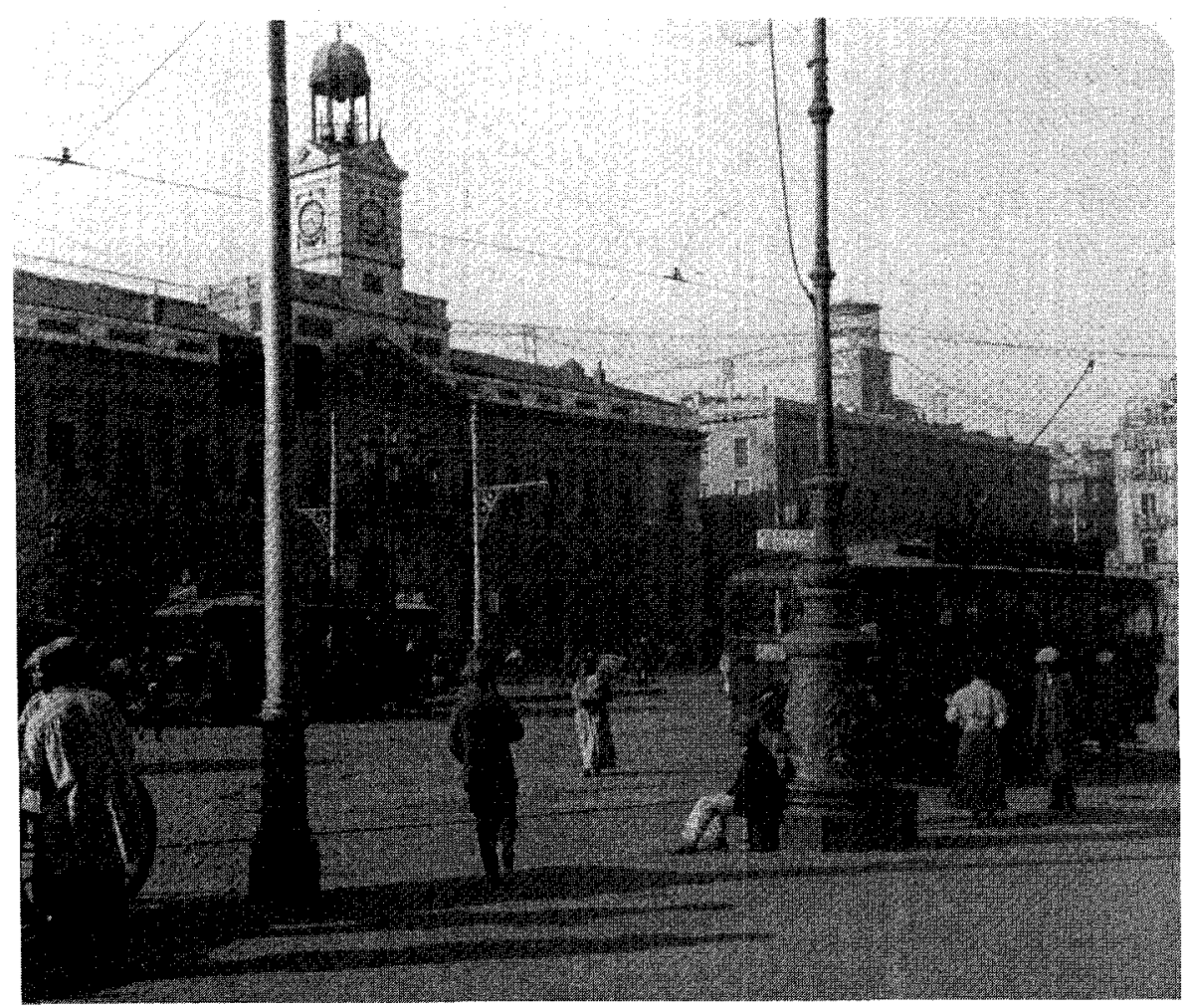

Fig. 12. Madrid, Puerta del Sol. 1905.

tenso cosmopolitismo como Venecia o París ${ }^{32}$, o enclaves del norte de África, debiendo destacar el extenso reportaje gráfico que realizó en la ciudad de Tánger en $1907^{33}$. Esta costumbre de los viajes fotográficos estuvo bien asentada en los operadores aficionados españoles, pues verbigracia Ramón y Cajal, aprovechando su estancia en 1899 en la estadounidense Universidad de Clark, en Worcester, tomó fotografías estereoscópicas. Sin ir más lejos, la revista La Esfera ${ }^{34}$ creó la sección

${ }^{32}$ El viaje a París lo hizo en 1912, fecha crucial para conocer el desarrollo de las vanguardias históricas, pues la ciudad parisina constituía el punto neurálgico del arte a nivel mundial. Muy probablemente Cerdá y Rico visitara alguna exposición, lo que le haría conocer de primera mano alguna de las corrientes artísticas. $Y$ el que visitara comercios fotográficos, le permitiría igualmente contactar con las últimas tendencias.

${ }_{33}$ Para profundizar en este tema ver LARA LóPEZ, E. L. «El africanismo a través de la fotografía de Arturo Cerdá y Rico. Tánger, 1907», en El Toro de Caña, 10, 2003, págs. 141-197.

${ }^{3} 4$ SÁnCHEZ ViGlL, J. M.: La Esfera. Ilustración mundial (1914-1931), Madrid, Libris, 2003. 
«España Artística y Monumental» con el fin de divulgar el rico patrimonio español, con lo cual se publicaban textos de viajes ilustrados con fotografías de monumentos, esculturas y obras pictóricas.

La infatigable experimentación de Cerdá le lleva a probar fortuna con la denominada fotografía directa. Esta corriente que aboga por la «fotografía pura» nace de la mano de Alfred Stieglitz ${ }^{35}$, y resulta la antítesis del pictorialismo: la clave de la fotografía directa es la aversión a cualquier alteración de la naturalidad, retocado o manipulado de los negativos o copias, pues se reputaba a la fotografía como un medio artístico legítimo en sí mismo, que no requería de maquillajes ni afeites para ser una modalidad artística más. Alfred Stieglitz, en 1907, toma una célebre fotografía titulada The Steerage (La cubierta del barco) ${ }^{36}$-el autor la considerará la mejor de toda su obra - en la que un grupo abigarrado de personas deambula por la cubierta del transatlántico de lujo Kaiser Wilhelm $/{ }^{37}$. Esta fotografía debió conocerla - y admirarla - Arturo Cerdá, pues toma varias muy similares con motivo del viaje que efectuó a Tánger en $1907^{38}$, y en varias ocasiones acudió a esta modalidad de fotografía directa (Fig. 13), sobre todo cuando quería registrar aspectos relacionados con la modernidad ${ }^{39}$.

Muchas de las instantáneas de Cerdá y Rico -estereoscópicas sobre todopueden ser encajadas en las coordenadas de la fotografía popular ${ }^{40}$, una modalidad en la que descolló por ejemplo el austriaco Alois Beer durante su viaje por tierra española en 1900 -sobresalen sus placas verascópicas-, pues gustaba de registrar -entre otras cosas- actividades comerciales desarrolladas en plena

35 Alfred Stieglitz (1864-1946) además del valor artístico de su impactante obra, fue la columna vertebral del grupo Photo-Secession, la revista Camera Work (1903-1917) y la galería 291, cauces para difundir la vanguardia fotográfica.

36 Puede verse en Newhall, B. Historia...op. cit., p. 169, o si se prefiere en KoEtzLE, H.-M.: Photo Icons. Petite histoire de la photo, vol. 1, Taschen, 2002, pág. 135.

37 Stieglitz paseaba por la cubierta de primera clase y vio el acusado contraste entre los pasajeros de mayor rango social y los más humildes, que viajaban en zonas diferentes del barco y presentaban un aspecto externo muy diferente; fue presto al camarote, cogió su cámara Gaflex, voivió a cubierta e hizo la foto.

38 Ver LARa LóPEZ, E. L.: “El africanismo... », op. cit.

39 En el transcurso de un viaje a Valladolid, Cerdá, interesado por unos trabajadores que manejaban una de las primeras máquinas de fabricar hormigón, toma una instantánea que puede verse en Registro de memorias..., op. cit., pág. 317. Asimismo, en dicho libro, pág. 486, apar€ce una foto tomada en Alicante en 1903 en la cual los trabajadores se congregan alrededor de una humeante caldera en la que se calienta asfalto para cubrir una calle. Curiosamente, en 1906 Adolfo Mas tomaría una foto, Obreros de la fábrica Hispano Suiza - Instituto Amatller de Arte Hispánico-, que adopta los mismos códigos narrativos que las hechas por Cerdá —aunque adolezca de la espontaneidad de las de éste- y que pude verse en La fotografía en España..., op. cit., pág. 342.

40 LóPEZ MONDÉJAR, P.: Historia..., op. cit., págs. 126-137, trata esta modalidad fotográfica, practicada mayoritariamente por operadores aficionados de provincias, y resalta en valor de muchas de estas obras en contraposición a la artificiosidad y códigos narrativos amojamados en que se desenvolvían los profesionales en sus estudios. 


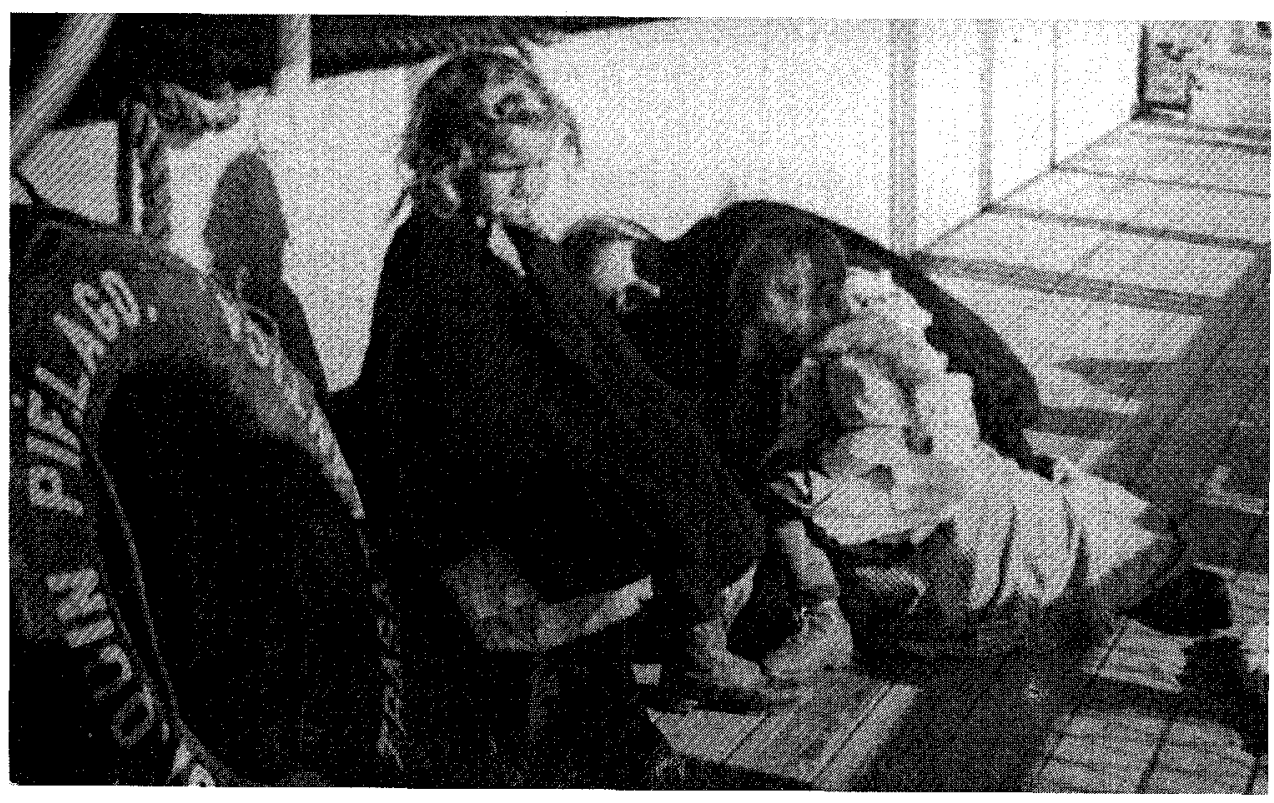

Fig. 13. Emigrantes, 1907.

calle ${ }^{41}$. El sacerdote mallorquín Tomás Monserrat, por ejemplo, destaca por la fuer$z a$ de sus retratos de gente humilde ${ }^{42}$, pero a nuestro juicio $-y$ sin pretensiones de grandilocuencia-, las fotos de Cerdá referidas a trabajos cotidianos, labores agrícolas y ganaderas y oficios artesanales superan con creces, por su técnica, pulsión emotiva y fuerza narrativa visual, a las de cualquier otro operador en el ámbito nacional. En este campo resaltan las series de fotografías de: lavaderos públicos - situados en diferentes poblaciones españolas-, trabajos de pesca en muelles y embarcaderos, pastoreo, recogida de aceituna, escenas de lagar, fabricación de tejas, lañadores, alfareros, toneleros, aladreros, caldereros (Fig. 14) fábricas de zapatos, carpinteros, cordeleros, barberos pelando al cero para eliminar los piojos

41 Ver VV. AA. Alois Beer. Un viaje fotográfico por la España de 1900. Eine fotografische reise durch Spanien um 1900, Madrid, Ayuntamiento de Madrid, 2000. Podrían destacarse un par de fotos que recogen una escena de mercado (pág. 182) y un aguador que demuestra su oficio (pág. 156), pues comparten los códigos narrativos visuales seguidos por Cerdá y Rico. De todas formas, la obra de Alois Beer no pudo influir en ningún sentido en la producción de Arturo Cerdá, pues fue en 1921 cuando el operador austriaco publicó su libro de fotografías La España desconocida. Arquitectura, paisajes y vida popular, que dedicó a Alfonso XIII, y Cerdá murió precisamente en febrero de 1921.

42 Ver LóPez MondéJAR, P.: Historia..., op. cit., pág. 129 la foto Retrato de campesina tomada en Llucmajor hacia 1920 . 


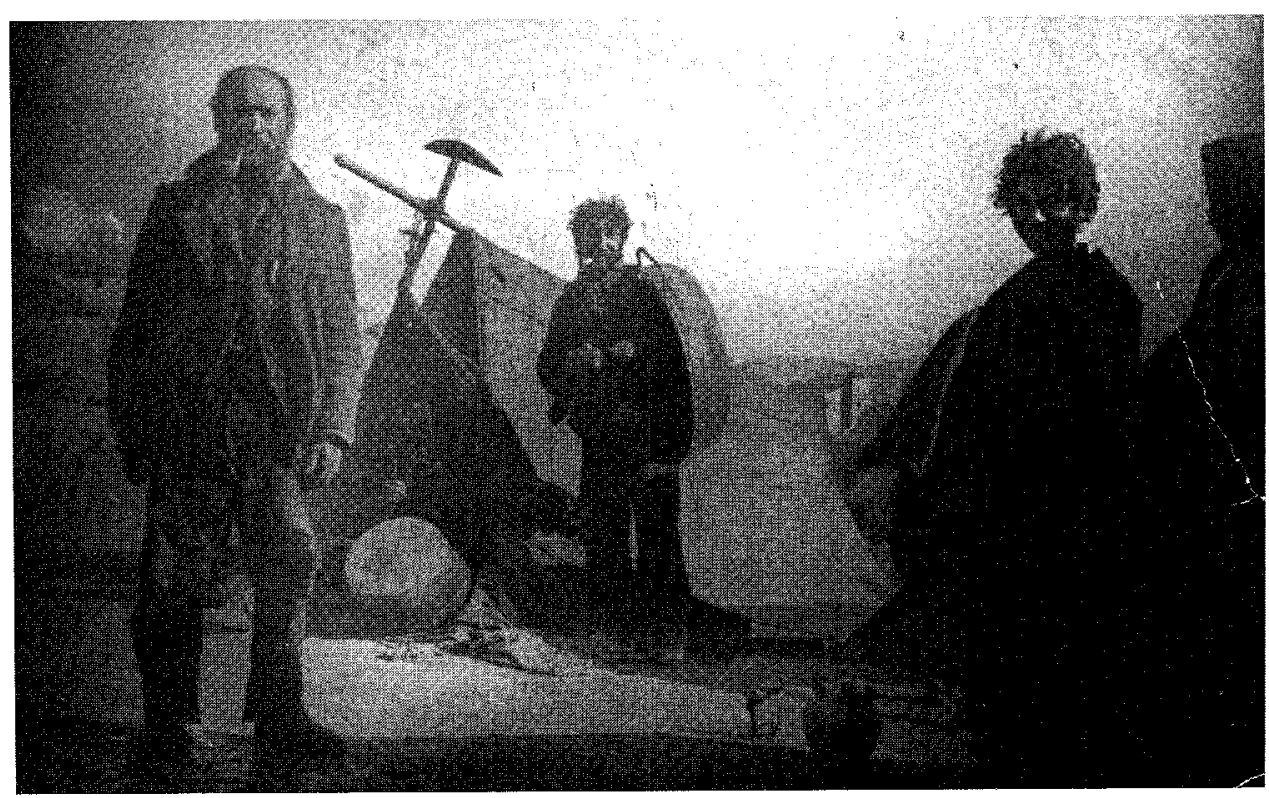

Fig. 14. Caldereros. 1904.

(Fig. 15) etc. En este abigarrado conjunto fotográfico, no cabe duda que debió influir la obra del resto de operadores aficionados jiennenses con los que tan continuado contacto tuvo Cerdá, pues además de reunirse en su tertulia, intercambiaban cristales estereoscópicos tomados por ejemplo por Bonifacio de la Rosa, Enrique Cañada Pérez, Ramón Espantaleón Molina o Jaime Roselióo ${ }^{43}$. Con lo cual, a nuestro entender, el núcleo de amateurs jiennenses constituyó, en la última fase vital de Arturo Cerdá, su referencia más cercana y entrañable.

Esas relaciones personales entre los diferentes operadores aficionados jiennenses respondían a la usual prácticá del asociacionismo fotográfico, que se convertirá en el músculo cultural de la burguesía afincada en las provincias españolas para convertir la fotografía en una auténtica institución social ${ }^{44}$.

A diferencia de los operadores norteamericanos, la fotografía documentalista no es pensada como un elemento de denuncia social, como un aldabonazo gráfico para criticar ante las autoridades e instituciones públicas las penosas condiciones de vida de determinados sectores sociales. Esto fue practicado por la llamada fotografía docu-

43 Ver La memoria en sepia..., op. cit.

44 INSENSER, E.: La fotografía en España en el periodo de entreguerras, 1914-1939, Gerona, Biblioteca de la Imagen, 2000, pág. 200. 


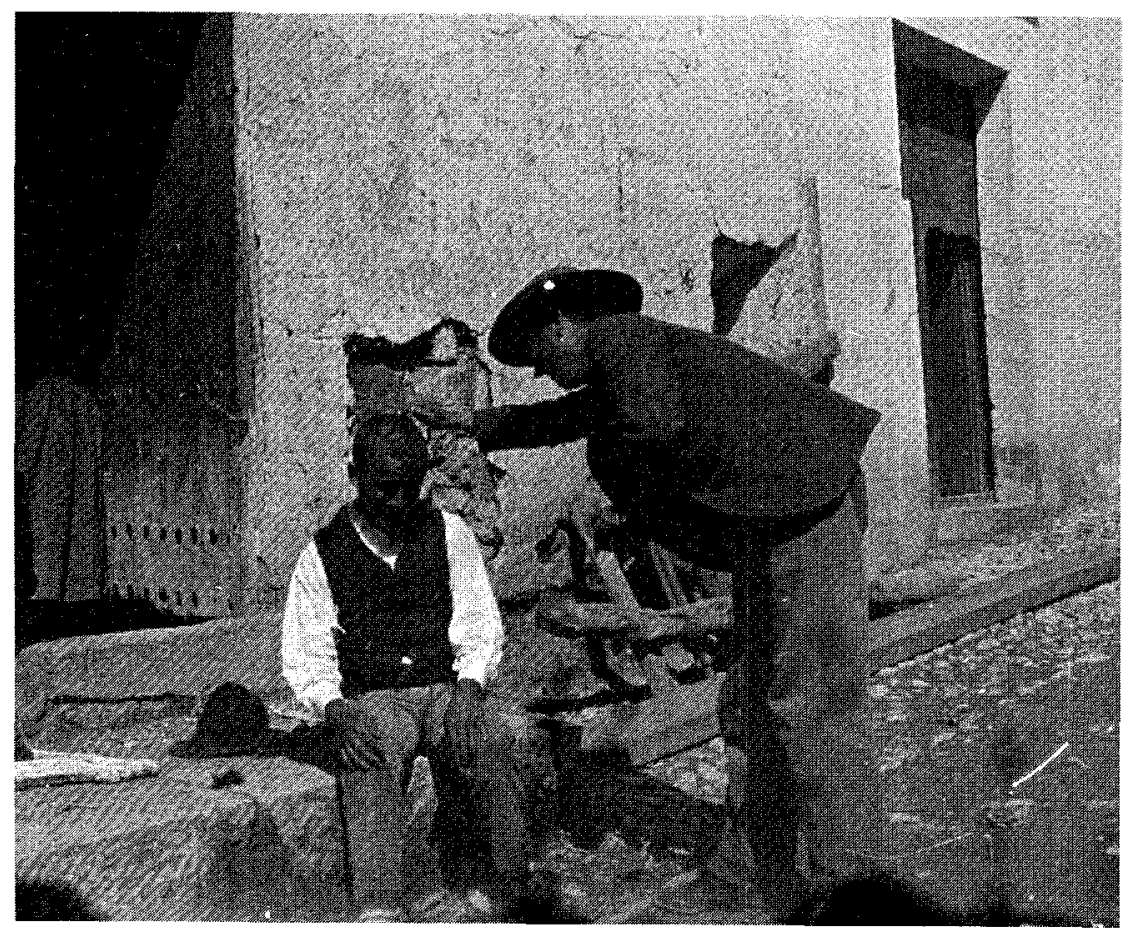

Fig. 15. Barbero. 1903.

mental, cuya génesis radica en las fotos que Lewis Wickes Hine -que estudió sociología en varias universidades estadounidenses - realizaba en la primera década del siglo $x x$ a los inmigrantes que arribaban a Nueva York, pues este operador estaba muy concienciado por el bienestar de los segmentos más desfavorecidos ${ }^{45}$. La fotografía documental consideraba que la cámara era un poderoso medio para la reivindicación social. Las instantáneas de Cerdá siguen apegadas a las fórmulas narrativas visuales que resaltan el tipismo y los estereotipos sociales, cuyo común denominador es que son visiones burguesas de la sociedad española y que no tienen como finalidad la realización de crítica alguna o de poner en tela de juicio las raíces de un sistema político -la monarquía liberal de Alfonso XIII--, sino únicamente la constatación fotográfica de gentes que llevan unos estilos de vida tradicionales.

${ }^{45}$ Este operador, en los años previos a la Gran Guerra, fotografió a los inmigrantes llegados a Nueva York en las fábricas y pequeños comercios donde trabajaban, así como a sus hijos jugando en los arrabales entre suciedad y el lumpen de los barrios bajos neoyorquinos. Empero, en 1918 abandona la crítica social y se decanta por fotografiar las labores asistenciales y humanitarias que la Cruz Roja realizaba en Centroeuropa con motivo de los desastres bélicos. 